\title{
Why we should ban the military use of satellites
}

Artificial earth satellites are becoming an integral part of the nuclear arms race. Bhupendra Jasani, of the Stockholm International Peace Research Institute, argues for a new Outer Space Treaty to control the military use of satellites.

The peaceful uses of satellites cannot be disputed. They have proved to be of enormous value in communications, meteorology, cartography, navigation and in verifying arms control agreements. The military use of artificial satellites, on the other hand, has not only been firmly established but has become a part of the arms race. The tendency now is to turn outer space into a battlefield of the future.

In the 20 years since the start of the space age, 1,482 military-oriented satellites have been launched, which represents about $75 \%$ of all satellites. Of these 1,482 , about $40 \%$ were photographic reconnaissance satellites. The remaining $60 \%$ have been used in all kinds of refinements in the technology of fighting wars on earth.

The functions of military satellites range from reconnaissance, navigation or communications to meteorology and geology. They are well on the way to being able to navigate lethal weapons to their targets with a high degree of accuracy; they can predict weather conditions to facilitate bombing; they can be used to pinpoint geographical positions with great precision so that no target can remain in obscurity; they increasingly mean that areas of war can be controlled remotely.

Surveillance and early-warning satellites have become an important part of strategic doctrine. New technology is now available to enhance their performance and to improve their survival chances against enemy attack. With the development of these types of satellites, there seems to be a trend towards a new doctrine of flexible response and limited nuclear war. In this new strategy, space technology can provide better centralised command and control over military forces. In a limited exchange of nuclear weapons it is necessary to assess damage quickly, to make a prompt response and to have precise target information. Reconnaissance satellites provide this capability.

The satellites mentioned so far can be used for peaceful as well as military purposes. But there also exists a category of satellites whose function is purely hostile-the interceptor-destructor satellites (or as they are often called, hunter-killer satellites). The development by the United States and the Soviet Union of satellites and systems for destroying satellites in orbit, has opened up space as yet another area in which man can wage war. Satellites which can hunt down another satellite and destroy it by exploding nearby have already been tested.

Discussions between the United States and the Soviet Union on banning the hunter-killer satellite begin this month. However, to ban only some military satellites will inevitably lead to the usual criticism of all partial disarmament measures. For example, the 1967 Outer Space Treaty only prohibits placing "in orbit around the Earth any objects carrying nuclear weapons or any other kind of weapons of mass destruction". In Article 4 of the treaty "the establishment of military bases, installations and fortification, the testing of any weapons and the conduct of military manoeuvres" are prohibited only on celestial bodies. The treaty has not helped to check the proliferation of military satellites. Therefore, it would seem appropriate to suggest that all military uses of artificial earth satellites be banned.

The fact that the premature re-entry into the earth's atmosphere of the Soviet Cosmos 954 ocean-surveillance satellite carrying a nuclear powered generator prompted President Carter to say "we would be glad to forgo the deployment of any such satellites altogether and will pursue that option along with the Soviet Union" may be a step in this direction. Between them, the Soviet Union and the United States have launched 38 satellites carrying nuclear power sources. At least four accidents are known to have occurred involving these satellites, two of which were military. In both cases there was radioactive contamination of the atmosphere and the earth's surface. Since military satellites are likely to use nuclear power sources rather than the conventional solar cells in order to make them less vulnerable to attack, it would be desirable, on environmental grounds alone, to ban such military satellites.

Any ban on satellites must be restricted to their military uses. Reconnaissance satellites for verifying arms control agreements and early-warning satellites help to stabilise the relationship between the two main nuclear powers. A step forward in arms control would be to enable more countries to take part in verification which, until 1975, when China emerged as a reconnaissance satellites power, was the monopoly of the USA and the USSR. An international control agency, preferably within the United Nations, should be created which would be the only organisation allowed to launch reconnaissance satellites for checking compliance with disarmament agreements.

This concept of internationalisation could and should be extended to all other satellites. International bodies are already in existence which could control both communications and meteorological satellites. Transmission frequencies used by communications satellites and their orbital data could be monitored by, for example, the International Telecommunications Union (ITU). The World Meteorological Organisation (WMO) could take on the task of controlling the use of meterological satellites. Controlling navigation satellites could be done by two other UN organisations, the inter-Governmental Maritime Consultative Organisation (IMCO) and the International Civil Aviation Organisation (ICAO).

There is no appropriate body within the UN to take on the task of controlling geodetic satellites. Outside the UN, however, one of the committees of the International Council of Scientific Unions (ICSU), the Committee on Space Research (COSPAR), could foster international cooperation and control in all scientific experiments that make use of rockets and satellites as research tools. This could include the use of geodetic satellites.

In any Comprehensive Outer Space Treaty, verification would be a difficult but not impossible problem to solve. It is possible from measurements of the orbital characteristics of satellites, the types of signals they transmit and estimations of their shape, weight and dimensions to determine their missions.

A number of nuclear arms control agreements have been reached so far but these have resulted in controlled armament rather than disarmament. At present the total nuclear arsenal of the nuclear-weapon powers is not increasing significantly. However, the quality and effectiveness with which such weapons can be delivered to their targets is improving dramatically. The artificial earth satellites play a major role in this trend. If, by banning the use of military satellites, the qualitative nuclear arms race could be checked, then it would mean that the nuclearweapon powers would be making a positive step towards fulfilling their pledge made in Article VI of the 1968 Treaty on the Non-Proliferation of Nuclear Weapons. 